\title{
DRYING AND ISOTHERMS OF SUGAR CANE BAGASSE
}

Joyce Maria Gomes da Costa ${ }^{1}$, Jefferson Luiz Gomes Corrêa ${ }^{2}$, Bruno Elyeser Fonseca ${ }^{3}$, Flávio Meira Borém ${ }^{4}$, Soraia Vilela Borges ${ }^{5}$

\begin{abstract}
Sugarcane is nowadays considered an important source of energy. One of its products is sugarcane bagasse. Bagasse is largely used as a boiler fuel. The goal of this work was to study bagasse drying in a fixed bed and its desorption isotherm. Air was used as drying agent at 40,50 and $60{ }^{\circ} \mathrm{C}$ at flow rate of $0.9 \mathrm{~m} \mathrm{~s}^{-1}$. Desorption isotherms were also obtained at 40 and $50{ }^{\circ} \mathrm{C}$. Several models from literature were tested with regards to their fit to fixed bed drying and desorption isotherm data. The best adjustments were obtained with Modified Page 2 model for drying kinetics and both the Jaafar and Michalowski model and modified Henderson 2 model for the desorption isotherm.
\end{abstract}

Keywords: biomass, drying, energy

\section{RESUMO}

\section{SECAGEM E ISOTERMAS DE BAGAÇO DE CANA DE AÇÚCAR}

A cana de açúcar é considerada, hoje em dia, como uma importante fonte de energia. Um de seus produtos é o bagaço de cana. O bagaço é muito utilizado como combustível para caldeiras. O objetivo deste trabalho foi o estudo da secagem de bagaço de cana em um leito fixo e de sua isoterma de desorção. $\mathrm{O}$ ar foi utilizado como agente de secagem a 40,50 e $60^{\circ} \mathrm{C}$ e $0,9 \mathrm{~m} \mathrm{~s}^{-1}$. As isotermas de desorção foram também obtidas a 40 e $50{ }^{\circ} \mathrm{C}$. Vários modelos da literatura foram testados para o ajuste da secagem em leito fixo e para os dados de isoterma. Os melhores ajustes foram obtidos com uma modificação do modelo de Page (modified Page 2), para cinética de secagem e com os modelos de Jaafar e Michalowski e uma modificação do modelo de Henderson (modified Henderson II) para as isotermas de desorção.

Palavras-chave: biomassa, secagem, energia.

Recebido para publicação em 20/02/2014. Aprovado em 23/12/2014.

1 - Engenheira de.Alimentos, Prof do UFVJM,/ICT/ Diamantina-MG, joyce.costa@ict.ufvjm.edu.br

2 - Engenheiro Químico, Prof da UFLA/Lavras-MG, jefferson@dca.ufla.br

3 - Engenheiro de Automação, Mestrando em Eng. de Sistemas e Automação, UFLA/Lavras-MG, brunoelyezerfonseca@yahoo.com.br

4 - Agrônomo, Prof. da UFLA/Lavras-MG, flavioborem@deg.ufla.br.

5 - Engenheira Química, Prof. da UFLA/Lavras-MG, sborges@dca.ufla.br

128 REVENG

128-142p. ENGENHARIA NA AGRICULTURA, VIÇOSA - MG, V.23 N.2, MARÇO / ABRIL 2015 


\section{INTRODUCTION}

Bagasse is the fibrous residue of sugarcane and is often used as a fuel in sugar and alcohol factories (LORA; ANDRADE, 2009, PALACIOSBERECHE et al., 2013) and for co-generation of electric energy (RÍPOLI et al., 2000). However, it can also be used in paper production (JAIN et al., 2009) as well as for bioethanol (DIAS et al., 2009; NGUYEN et al., 2009; PALACIOSBERECHE et al., 2013), as substrate for plantlet production (MORGADO et al., 2000), for compost formulations (MODA et al., 2005; SIQUEIRA et al., 2009) and animal feed (ROCHA et al., 2004; PEREIRA et al., 2008).

Whatever the final use, the majority of moisture content should be removed before further processing (KROKIDA et al., 2002; DOYMAZ et al., 2004). Although the most common industrial dryer for sugarcane bagasse is the pneumatic type (SOSA-ARNAO et al., 2006, BELTING ; SEMRAU, 2009), academic works have also address pneumatic (NEBRA ; MACEDO, 1988; ALARCÓN ; JÚSTIZ, 1993) cyclonic (CORRÊA et al., 2004, DE OLIVEIRA et al., 2011), fixed bed (VIJAYARAJ et al., 2007) and vacuum drying (PURANIK ; YARNAL, 2009).

Sorption isotherms relate the moisture content to the relative humidity for a product at a constant temperature. This relation depends on factors like physical structure, affinity of the material with water, the amount of water-soluble solutes and the growth rate of the process microorganism in the fermented sugarcane bagasse (KUROZAWA et al., 2005; FURMANIAK et al., 2009; MAZUTTI et al., 2010). Sorption isotherms are necessary to model drying and moisture uptake, as well as to design equipment and extend the product useful life (De TERMMERMAN et al., 2008).

The goal of this work was to study sugarcane bagasse drying in a fixed bed and its desorption isotherm. Fixed bed drying was performed at 40 , 50 and $60{ }^{\circ} \mathrm{C}$ and the desorption isotherms, at 40 and $50{ }^{\circ} \mathrm{C}$. Mathematical models from literature were tested for both the desorption isotherm and fixed bed drying.

\section{MATERIALS AND METHODS}

Sugarcane [Saccharum officinarum L.] bagasse was provided by the Junqueira sugar company (COSAN), located in Iguarapava, São Paulo, Brazil, and by Ester sugar company, Cosmópolis, São Paulo, Brazil. These factories extract juice from the sugarcane by milling.

The experiments were performed at the Federal University of Lavras, in the Department of Food Science and the Department of Agricultural Engineering.

The bagasse from both sources was characterized via sieve analysis with a set of standardized sieves (Tyler series: 4, 8, 14, 28, 35 and 48). The sieves were agitated for 20 minutes. This agitation time was established by verifying that additional time did not affect the mass fraction of product on each sieve.

Determination of the total moisture content was determined by the oven drying method at $105{ }^{\circ} \mathrm{C}$ for $24 \mathrm{~h}$ (AOAC, 1990), as described by Rasul et al. (1999).

The fixed bed drying and desorption isotherm experiments were performed using a dryer with a laboratory air conditioning unit (Figure 1), produced by Consciente Ltda, Belo Horizonte, Minas Gerais, Brazil.

This device permits defining the relative humidity and air velocity. Air velocity was measured using a digital anemometer and was set to an experimentally determined velocity that would maintain the bagasse in the fixed bed for both the drying and isotherm experiments and would prevent material loss during the experiments. The range of velocities used was selected based on the terminal velocity of the smallest particles, according to the study of Nebra and Macedo (1988). Because of the diversity of particle shapes and sizes in the bagasse, the experiments were carried out only with particles from sieves $4,8,14$, and 28 of the complete sieve analysis (Tyler series sieves 4, 8 , $14,28,35$ and 48). 


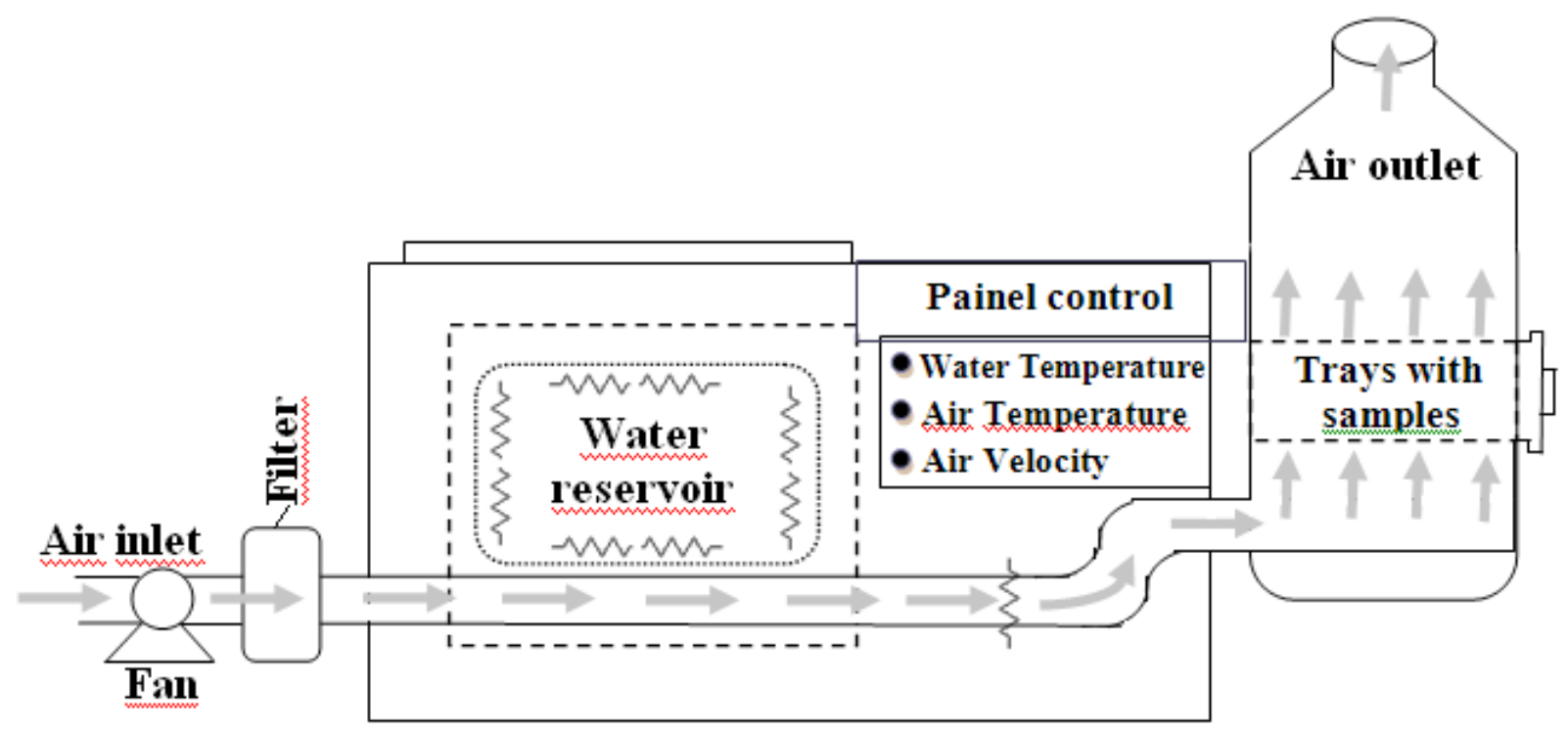

Figure 1. Dryer with Laboratory Air Conditioning Unit (setup).

The drying experiments were performed with samples obtained after milling with moisture content of $71.0 \%$ w.b., from the Junqueira sugar company (COSAN).

The experiments consisted of the passage of heated air (relative humidity of $25 \%$ and temperature of 40,50 and $60^{\circ} \mathrm{C}$ ) across the sample through a deep tray with a perforated screen. The wet bagasse layer had a volume of $1.984 \times 10^{-3}$ $\mathrm{m}^{3}$, a mass of $1000 \times 10^{-3} \mathrm{~kg}$ and a thickness of approximately $3.5 \times 10^{-2} \mathrm{~m}$. The air velocity was approximately $0.9 \mathrm{~m} \mathrm{~s}^{-1}$. The material was weighed on a scale with a resolution of $0.0001 \times 10^{-3} \mathrm{~kg}$ until the mass variations were less than $0.02 \times 10^{-3} \mathrm{~kg}$. Curves of the drying kinetics were obtained for all of the operational conditions considered in this work.

The desorption isotherm experiments were carried out on bagasse samples, which were obtained from the Ester sugar company and had a moisture content (w.b.) of $46 \%$ after milling. These samples were packaged in hermetic bags and refrigerated $\left(6{ }^{\circ} \mathrm{C}\right)$ until performing the laboratory experiments, which were performed two days after milling.

The direct method was used to determine the isotherms, with heated air at predefined values of relative humidity $(25,35,45,55,65$ and $75 \%)$, temperature $\left(40\right.$ and $\left.50^{\circ} \mathrm{C}\right)$ and velocity $\left(0.9 \mathrm{~m} \mathrm{~s}^{-1}\right)$, and a mass of wet sugarcane bagasse equal to 1.35 x $10^{-1} \mathrm{~kg}$.

The conditions used were the same as in the drying tests, with a wet bagasse layer presenting a volume of $1.984 \times 10^{-3} \mathrm{~m}^{3}$, mass of $100 \times 10^{-3} \mathrm{~kg}$ and thickness of approximately $3.5 \times 10^{-2} \mathrm{~m}$.

Mathematical models to describe the drying kinetics and isotherms are shown below. It is important to note that predictions for the drying experiments and desorption isotherms were performed with a quasi-Newton estimation method, with a convergence criterion of $1.00 \times 10^{-}$ ${ }^{4}$, an initial value of 0.10 and an initial estimate of 0.50 , for all of the model parameters.

The drying data was fitted with thirteen semitheoretical fixed bed drying models (Table 1), where $M_{r}$ for each model was obtained using equation 1 :

$M_{r}=\frac{X_{t}-X_{q}}{X_{i}-X_{q}}$

In this series of equations, $\mathrm{M}_{\mathrm{r}}$ is defined as the moisture ratio, $X_{t}$ is the moisture content at time $t$

\section{REVENG 128-142p.}


(w.b.) $\left[\mathrm{kg} \mathrm{kg}^{-1}\right], \mathrm{X}_{\mathrm{i}}$ is the moisture content at time 0 (w.b.) $\left[\mathrm{kg} \mathrm{kg}^{-1}\right], \mathrm{X}_{\mathrm{eq}}$ is the equilibrium moisture content (w.b.) $\left[\mathrm{kg} \mathrm{kg}^{-1}\right], \mathrm{t}$ is time [min] and $\mathrm{k}, \mathrm{k}_{0}$, and $\mathrm{k}_{1}$ are the drying constants $\left[\mathrm{min}^{-1}\right]$.

$\mathrm{R}^{2}=\frac{p_{\mathrm{i}=1}^{\mathrm{n}}(\mathrm{PRED}-\overline{\mathrm{OBS}})^{2}}{p_{\mathrm{i}=1}^{\mathrm{n}}(\mathrm{OBS}-\overline{\mathrm{OBS}})^{2}}$

The desorption data was fitted to thirteen sorption isotherm models by a non-linear regression. The mathematical models were of two types: those not considering temperature and/or vapor pressure as variables (Table 2) and those considering temperature and/or vapor pressure as variables (Table 3 ).

Fit was determined using the coefficient of determination $\left(\mathrm{R}^{2}\right)$ and the estimated standard error (SE), calculated by:

$\mathbb{E}=\sqrt{\frac{\$ \mathrm{p} i=1}{\mathrm{n}(\text { OBS }- \text { PRED })^{2}}}$

where OBS corresponds to observed value, $\overline{\mathrm{OBS}}$ corresponds to the average value of all observed values, PRED is the predicted value and $\mathrm{n}$ is the number of observations (JAAFAR; MICHALOWSKI, 1990).

Table 1. Mathematical models used to describe the fixed bed drying of sugarcane bagasse.

\begin{tabular}{|c|c|c|}
\hline Model & Equation & Reference \\
\hline Newton & $\mathrm{M}_{\mathrm{r}}=\mathrm{e}^{-\mathrm{kt}}$ & Ayensu, 1997, Shi et al., 2008 \\
\hline Page & $\mathrm{M}_{\mathrm{r}}=\mathrm{e}^{-\mathrm{k}^{\mathrm{n}}}$ & Page (1949) \\
\hline Modified Page 1 & $M_{r}=e^{\left.(-k)^{n}\right)}$ & Sobukola et al., 2008 \\
\hline Modified Page 2 & $\mathrm{M}_{\mathrm{r}}=\mathrm{e}^{\left(-(\mathrm{kt})^{\mathrm{n}}\right)}$ & Overhults et al., 1973 \\
\hline Henderson and Pabis & $\mathrm{M}_{\mathrm{r}}=\mathbf{a}^{(-\mathrm{kt})}$ & Henderson and Pabis (1961) \\
\hline Logarithmic & $\mathrm{M}_{\mathrm{r}}=\mathbf{a}^{(-\mathrm{kt})}+\mathrm{c}$ & Doymaz, 2008, 2006 \\
\hline Two term & 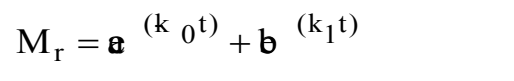 & Madhiyanon et al., 2009 \\
\hline Two term exponential & $M_{r}=\mathbf{a}^{(-k t)}+(1-a) e^{(-k a t)}$ & Sharafeldeen et al., 1980 \\
\hline Wang and Singh & $M_{r}=1+\mathfrak{a}+b^{2}$ & Wang and Singh, (1978) \\
\hline $\begin{array}{l}\text { Approximation } \\
\text { of diffusion }\end{array}$ & $\mathrm{M}_{\mathrm{r}}=\mathbf{a}^{(-\mathrm{kt})}+(1-\mathrm{a}) \mathrm{e}^{(-\mathrm{kbt})}$ & Yaldiz and Ertekin, 2001 \\
\hline Verma & $M_{r}=\mathbf{a}^{(-k t)}+(1-a) e^{\left(-k_{1} t\right)}$ & Verma and Shukla (2000) \\
\hline $\begin{array}{l}\text { Modified Henderson } \\
\text { and Pabis }\end{array}$ & $\mathrm{M}_{\mathrm{r}}=\mathbf{a}^{(-\mathrm{k})}+\mathrm{b}^{\left(\mathrm{k} 0^{y}\right)}+\mathrm{e}^{\left(\mathrm{k}_{1}\right)}$ & Madhiyanon et al., 2009 \\
\hline Midilli & $\mathrm{M}_{\mathrm{r}}=\mathrm{a}^{\left(\mathrm{k}^{\mathrm{n}}\right)}+\mathrm{b}$ & Midilli et al., (2002) \\
\hline
\end{tabular}


Table 2. Mathematical models that were used to describe the desorption isotherm of sugarcane bagasse not considering temperature and vapor pressure of saturation as a variable.

\begin{tabular}{|c|c|c|}
\hline Model & Equation & Reference \\
\hline $\begin{array}{l}\text { Jaafar and } \\
\text { Michalowski }\end{array}$ & $\mathrm{X}=\frac{\mathrm{S}_{1} \mathrm{~S}_{2}}{\left(1-\mathrm{S}_{3} \phi\right)\left[1+\left(\mathrm{S}_{2} \mathrm{~S}_{3}\right) \phi\right]}$ & Jaafar and Michalowski (1990) \\
\hline $\begin{array}{l}\text { Hailwood and } \\
\text { Horrobin }\end{array}$ & $\frac{\ddot{\mathrm{o}}}{\mathrm{X}}=\mathrm{S}_{1} \mathrm{~S}_{2} \boldsymbol{\delta}{ }_{3} \ddot{\mathrm{o}}^{2}$ & Hailwood and Horrobin (1946) \\
\hline $\begin{array}{l}\text { Anderson and } \\
\text { Hall }\end{array}$ & $\mathrm{X}=\frac{\mathrm{S}_{1} \mathrm{~S}_{2} \mathrm{~S}_{3} \phi}{\left(1-\mathrm{S}_{4} \mathrm{~S}_{3} \phi\left[1+\left(\mathrm{S}_{2}-\mathrm{S}_{4}\right) \mathrm{S}_{3} \phi\right]\right.}$ & Anderson and Hall (1948) \\
\hline Peleg & $X=s_{1} \exp \left(s_{2} h \phi\right)+s_{3} \phi^{s^{4}}$ & Peleg (1993) \\
\hline $\begin{array}{l}\text { Huttig and } \\
\text { Theimer }\end{array}$ & $\frac{X}{S_{1}}=\frac{\phi S_{2}}{1+\phi S_{2}}$ & Huttig and Theimer (1950) \\
\hline Caurie & h $X=\ln \left(S_{1}\right)-\phi S_{2}$ & Caurie (1970) \\
\hline Kühn & $\mathrm{X}=\frac{\mathrm{S}_{1}}{\mathrm{~h} \phi}+\mathrm{S}_{2}$ & Kühn (1964) \\
\hline $\begin{array}{l}5^{\text {th }} \text { degree } \\
\text { polynomial }\end{array}$ & $\phi=\mathrm{S}_{1}+\mathrm{S}_{2} \mathrm{X}+\mathrm{S}_{3} \mathrm{X}^{2}+\mathrm{S}_{4} \mathrm{X}^{3}+\mathrm{S}_{5} \mathrm{X}^{4}$ & (Pakowski, 1995) \\
\hline Harkins and Jura & $\mathrm{h} \phi=\mathrm{S}_{1}-\frac{\mathrm{S}_{2}}{\mathrm{X}^{2}}$ & Harkins and Jura (1944) \\
\hline Halsey & $\phi=\frac{\mathrm{S}_{1}}{\mathrm{e}^{\mathrm{S}_{2} \mathrm{X}^{-S_{3}}}}$ & Halsey (1983) \\
\hline
\end{tabular}

Table 3. Mathematical models used to describe the desorption isotherm of sugarcane bagasse considering temperature and vapor pressure of saturation as a variable.

\begin{tabular}{lll}
\hline Model & Equation & Reference \\
\hline Modification Henderson I & $\mathrm{h}(1-\phi)=-\mathrm{s}_{1} \mathrm{~T}+\mathrm{s}_{2} \mathrm{X}^{\mathrm{s}_{3}}$ & (Pakowski, 1995) \\
Modification Henderson II & $\phi=\mathrm{s}_{3}\left(1-\exp \left(-\mathrm{s}_{1} \mathrm{X} \quad \mathrm{s}_{2}\right)\right)$ & (Pakowski, 1995) \\
Modification Henderson III & $\phi=1-\exp \left[-\mathrm{s}_{1}\left(\mathrm{~s}_{2}+\mathrm{T}\right) \mathrm{X}^{\mathrm{S}_{3}}\right)$ & (Madamba et al., 1995)
\end{tabular}

\section{REVENG




\section{RESULTS AND DISCUSSION}

Figures 2 and 3 show the particle size distribution characterized by sieve analysis, with Figure 2 showing the size distributions of sugarcane bagasse from the Junqueira sugar company (COSAN) and Figure 3 showing the size distribution of bagasse from the Ester sugar company.

Sugarcane bagasse contains diverse particle sizes and shapes. The difference between size distributions shown in Figure 2 and 3 is mainly related to the moisture content of the samples. Because bagasse from the Junqueira sugar company presents higher moisture content, the smaller particles of this bagasse tend to agglomerate.

Figure 4 shows the predicted drying results obtained with the Modified Page 2 model. If considering agreement based on the $\mathrm{R}^{2}$ and standard error (SE), this model provided the best agreement with the experimental data for all studied temperatures. This is an empirical model that is traditionally applied to predict drying of diverse agricultural products (DOYMAZ, 2004; GUNHAN et al., 2005; CAI; CHEN, 2008). It was observed (Figure 4) that the drying rate is directly proportional to the temperature, corroborating innumerable drying results from literature, such as the works of Gunhan et al. (2005), Hossain et al. (2007); Shi et al. (2008) and Sobukola et al. (2008).

It was observed that for all three temperatures used in the drying process, the $\mathrm{R}^{2}$ values describing the agreement of most of the mathematical models presented with the experimental data (Table 4) were close to 0.9000 , indicating a satisfactory representation of the drying process. The exception to this was the Modified Page 1 model which showed no agreement.

Table 5 and 6 show the parameters that were obtained when the mathematical models were compared to the experimental sugarcane bagasse desorption isotherms at 40 and $50^{\circ} \mathrm{C}$, respectively.

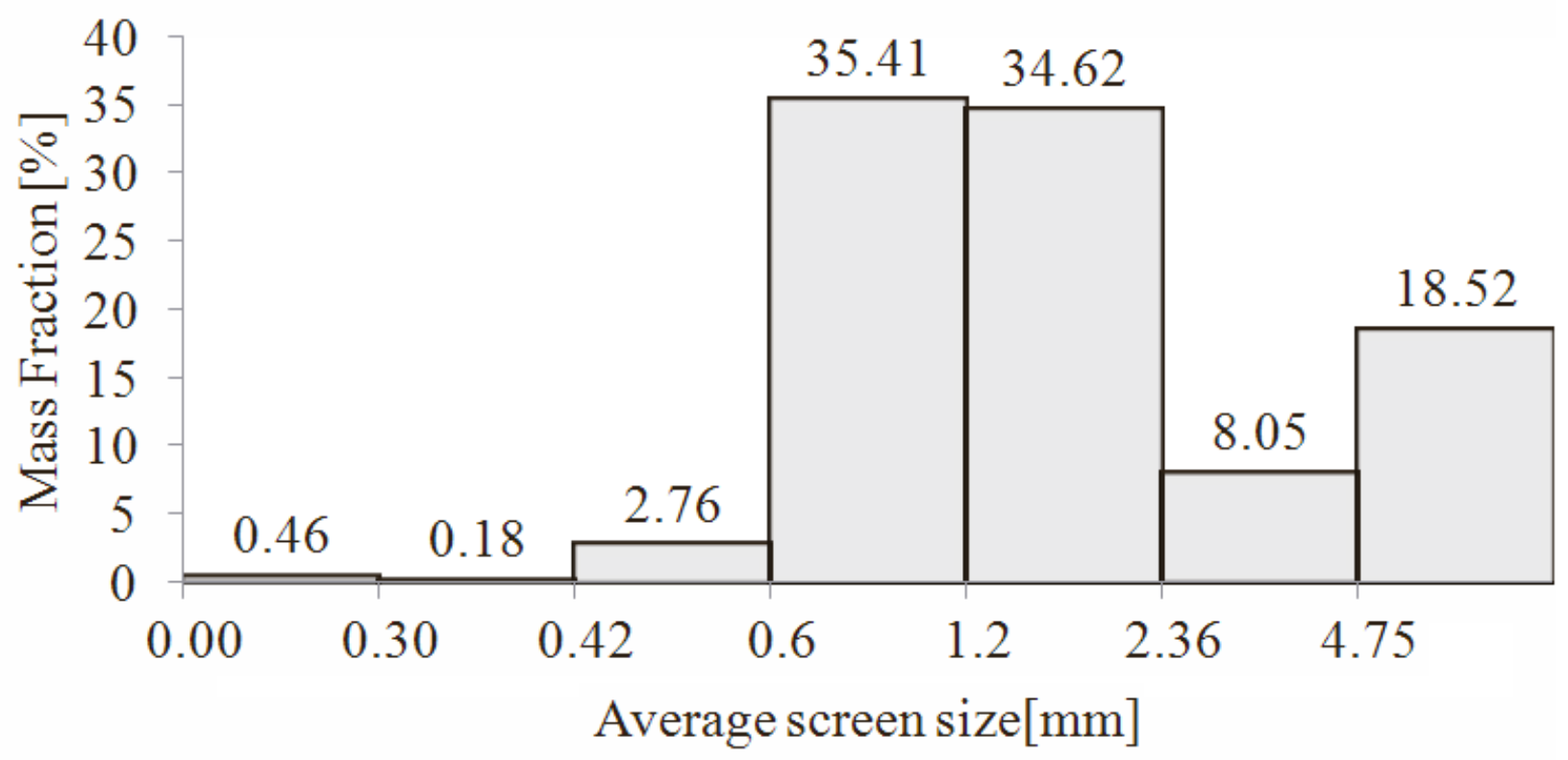

Figure 2. Particle size distribution, determined by sieve analysis, of bagasse (the Junqueira sugar company) with a moisture content of $71.0 \%$ (w.b.). 


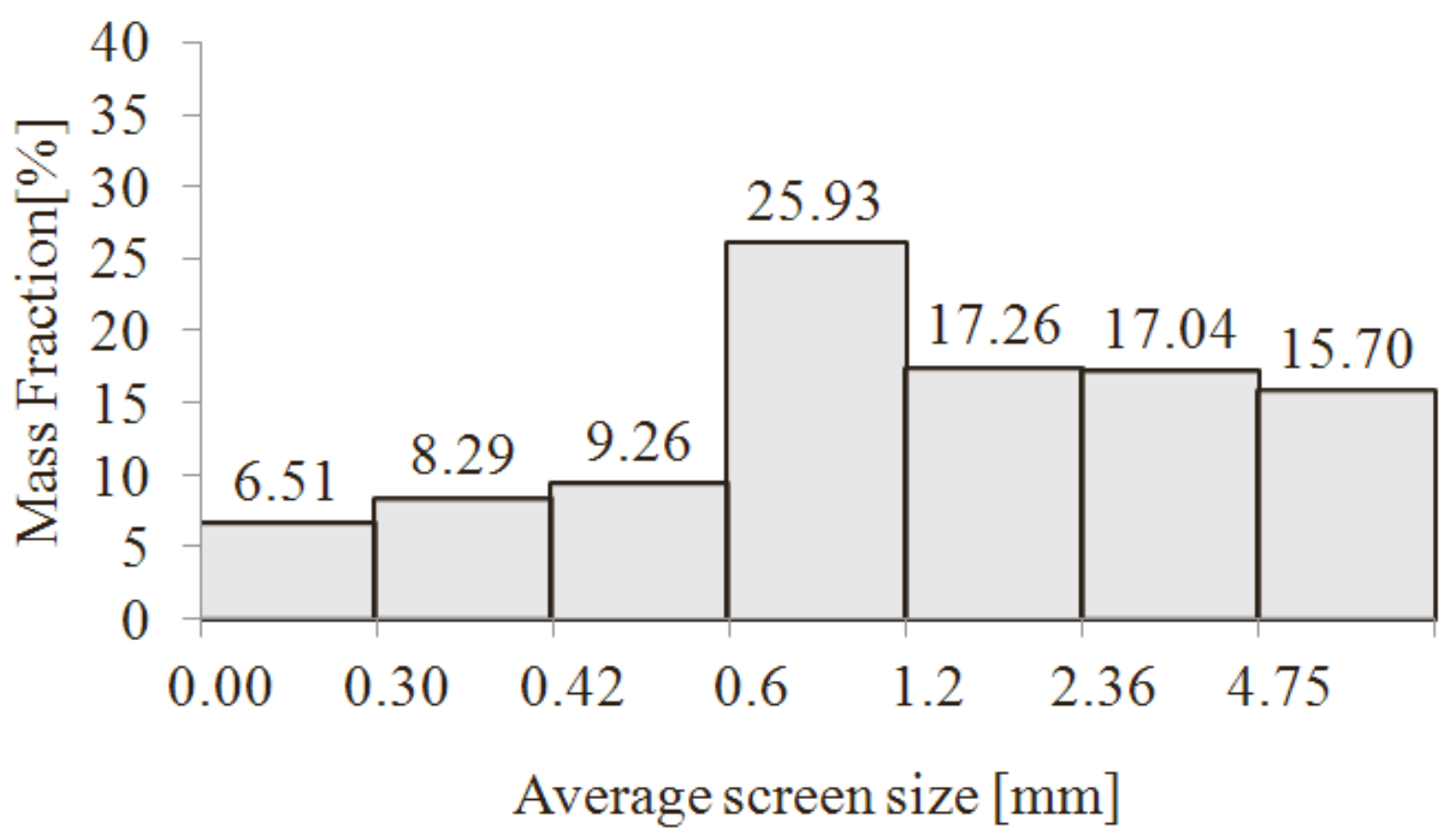

Figure 3. Particle size distribution, determined by sieve analysis, of bagasse (Ester sugar company) with a moisture content of $8.0 \%$ (w.b.).

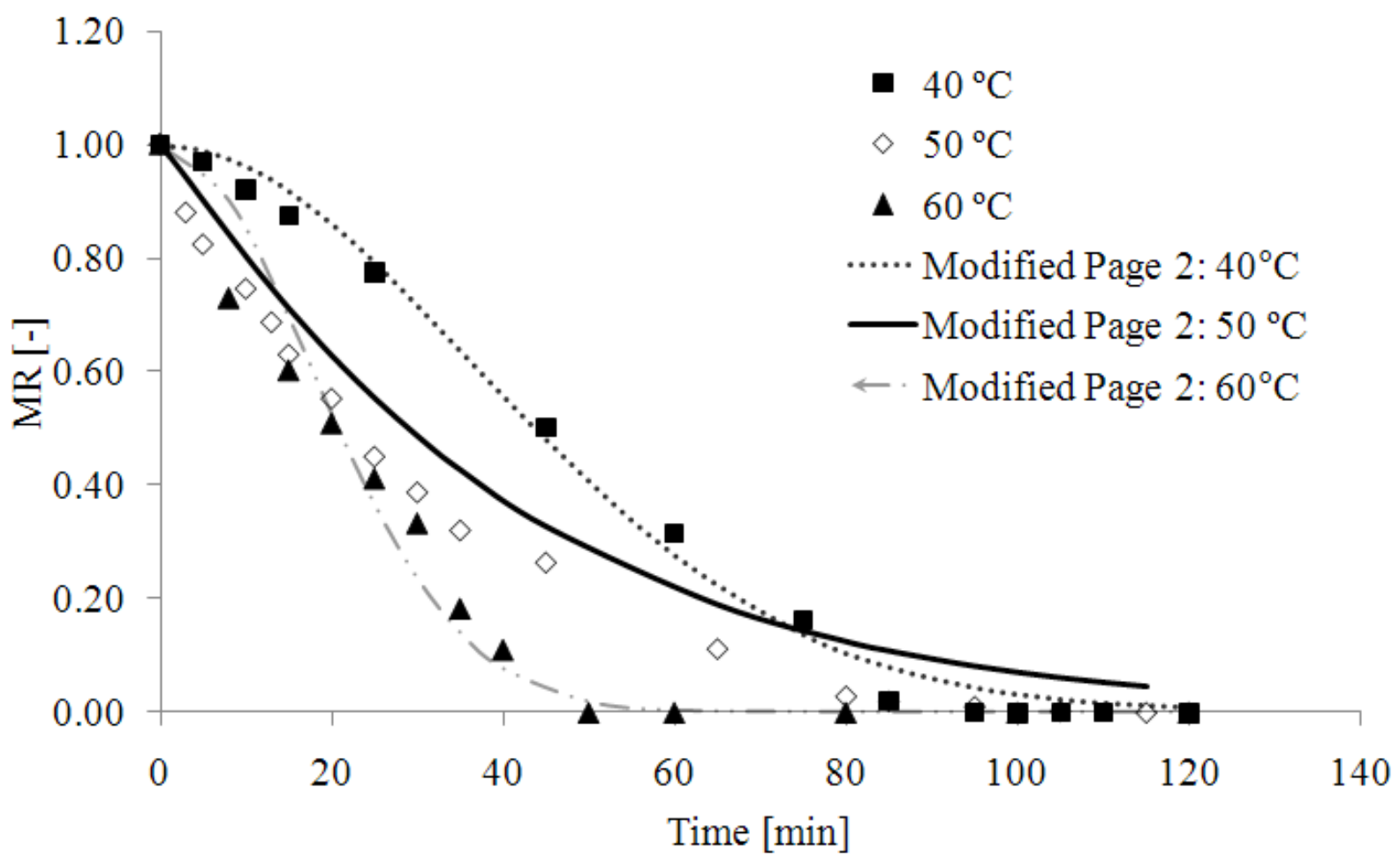

Figure 4. Drying kinetics of sugarcane bagasse at different temperatures and comparison with the Modified Page 2 model. 
Table 4. Agreement of mathematical models with the experimental sugarcane bagasse drying results at the temperatures of 50,60 and $70{ }^{\circ} \mathrm{C}$.

\begin{tabular}{|c|c|c|c|c|}
\hline Equation & Constants & $50^{\circ} \mathrm{C}$ & $60^{\circ} \mathrm{C}$ & $70^{\circ} \mathrm{C}$ \\
\hline \multirow{8}{*}{$\begin{array}{c}\text { Newton (Ayensu, 1997; Shi et al., } \\
\text { 2008) }\end{array}$} & $\mathrm{k}$ & 0.084785 & 0.099209 & 0.138714 \\
\hline & $\mathrm{R}^{2}$ & 0.92273 & 0.99988 & 0.92639 \\
\hline & $\mathrm{SE}$ & 0.00461 & 0.00448 & 0.00437 \\
\hline & $\mathrm{k}$ & 0.012002 & 0.014503 & 0.017706 \\
\hline & $\mathrm{n}$ & 1.755319 & 1.779354 & 1.960761 \\
\hline & & & & \\
\hline & $\mathrm{R}^{2}$ & 0.99611 & 0.99999 & 0.99865 \\
\hline & SE & 0.00232 & 0.00210 & 0.00008 \\
\hline * Modified Page 1 & & & & \\
\hline (Sobukola, et al. 2008) & & & & \\
\hline \multirow{4}{*}{$\begin{array}{c}\text { * Modified Page } 2 \text { (Overhults et } \\
\text { al., 1973) }\end{array}$} & $\mathrm{k}$ & 0.080491 & 0.09262 & $1.01 \mathrm{E}-05$ \\
\hline & $\mathrm{n}$ & 1.755319 & 1.77935 & $5.18 \mathrm{E}-10$ \\
\hline & $\mathrm{R}^{2}$ & 0.99999 & 0.99655 & --------- \\
\hline & $\mathrm{SE}$ & 0.00232 & 0.00210 & 0.06026 \\
\hline \multirow{4}{*}{ Henderson and Pabis (1961) } & $\mathrm{a}$ & 1.170492 & 1.17534 & 1.193599 \\
\hline & $\mathrm{k}$ & 0.098122 & 0.11437 & 0.160387 \\
\hline & $\mathrm{R}^{2}$ & 0.95056 & 0.9524 & 0.95220 \\
\hline & SE & 0.00295 & 0.00290 & 0.00284 \\
\hline \multirow{5}{*}{$\begin{array}{c}\text { Logarithmic } \\
\text { (Doymaz, 2006, 2008) }\end{array}$} & a & 1.523805 & 1.35218 & 1.247573 \\
\hline & $\mathrm{k}$ & 0.049851 & 0.07269 & 0.132021 \\
\hline & $\mathrm{c}$ & -0.43327 & -0.24005 & -0.0849 \\
\hline & $\mathrm{R}^{2}$ & 0.98881 & 0.98155 & 0.96605 \\
\hline & SE & 0.00067 & 0.00112 & 0.00202 \\
\hline
\end{tabular}


Table 5. Parameters of the desorption isotherms model and agreements for sugarcane bagasse at $40^{\circ} \mathrm{C}$, not considering temperature and vapor pressure of saturation as a variable.

\section{Constants}

Models

$\begin{array}{lllllll}\mathrm{S}_{1} & \mathrm{~S}_{2} & \mathrm{~S}_{3} & \mathrm{~S}_{4} & \mathrm{~S}_{5} & \mathrm{R}^{2} & \mathrm{SE}\end{array}$

\begin{tabular}{|c|c|c|c|c|c|c|c|}
\hline $\begin{array}{c}\text { Jaafar and } \\
\text { Michalowski } \\
\text { (1990) }\end{array}$ & 0.031 & 92849 & 1.12057 & -------- & -------- & 0.9604 & 0.0097 \\
\hline $\begin{array}{l}\text { Hailwood and } \\
\text { Horrobin (1946) }\end{array}$ & -556 & 1781.7 & -1379.7 & -------- & -------- & -------- & 0.0525 \\
\hline $\begin{array}{c}\text { Anderson and } \\
\text { Hall (1948) }\end{array}$ & 0.031 & 118.96 & 26.5359 & 0.0422 & ------- & 0.9603 & 0.0098 \\
\hline $\begin{array}{l}\text { Peleg } \\
(1993)\end{array}$ & 0.137 & 1.7407 & 0.13755 & 1.7407 & ------- & 0.7547 & 0.0243 \\
\hline $\begin{array}{l}\text { Huttig and Theimer } \\
\qquad(1950)\end{array}$ & 305.8 & 0.0004 & --------- & ------- & ------- & 0.7466 & 0.0248 \\
\hline Caurie (1970) & 0.014 & -3.345 & --------- & ------- & ------- & 0.8535 & 0.0188 \\
\hline Kühn (1964) & -0.05 & 0.0050 & --------- & ------- & ------- & 0.9090 & 0.0149 \\
\hline $\begin{array}{l}\text { Polinômio de } 5^{\circ} \\
\text { (Pakowski, 1995) }\end{array}$ & -12.0 & 541.28 & -8510.0 & 56975 & -13224 & 0.9090 & 0.0074 \\
\hline $\begin{array}{l}\text { Harkins and Jura } \\
\text { (1944) }\end{array}$ & -0.17 & 0.0030 & -------- & -------- & ------- & 0.9438 & 0.0405 \\
\hline Halsey (1983) & 0.799 & 0.0006 & 2.5575 & & ------- & 0.9662 & 0.0314 \\
\hline
\end{tabular}


Table 6. Parameters of the desorption isotherm models and agreements for sugarcane bagasse at $50{ }^{\circ} \mathrm{C}$, not considering temperature and vapor pressure of saturation as a variable.

Constants

Models

$\begin{array}{lllllll}\mathrm{S}_{1} & \mathrm{~S}_{2} & \mathrm{~S}_{3} & \mathrm{~S}_{4} & \mathrm{~S}_{5} & \mathrm{R}^{2} & \mathrm{SE}\end{array}$

Jaafar and

Michalowski

$0.0207 \quad 33498 \quad 1.1835$

0.9809

0.0071

(1990)

Hailwood and

Horrobin (1946)

0.3968

0.0398

\begin{tabular}{|c|c|c|c|c|c|c|c|}
\hline $\begin{array}{l}\text { Anderson and } \\
\text { Hall (1948) }\end{array}$ & 0.0207 & 9901.3 & 4.1298 & 0.2866 & ------- & 0.9808 & 0.0072 \\
\hline $\begin{array}{l}\text { Peleg } \\
(1993)\end{array}$ & 0.1837 & 2.7756 & 0.18367 & 2.7756 & ------- & 0.7988 & 0.0229 \\
\hline $\begin{array}{l}\text { Huttig and Theimer } \\
\qquad(1950)\end{array}$ & 375.64 & 0.0003 & ------- & ------- & ------- & 0.6864 & 0.0287 \\
\hline Caurie (1970) & 0.0052 & -4.662 & ------- & ------- & ------- & 0.8774 & 0.0179 \\
\hline Kühn (1964) & -0.051 & -0.014 & ------- & ------- & ------- & 0.8929 & 0.0168 \\
\hline $\begin{array}{l}\text { Polinômio de } 5^{\circ} \\
\text { (Pakowski, 1995) }\end{array}$ & -2.014 & 112.46 & -1844.6 & 13437 & -34084 & 0.9753 & 0.0268 \\
\hline $\begin{array}{l}\text { Harkins and Jura } \\
\qquad(1944)\end{array}$ & -0.216 & 0.0015 & ------- & ------- & ------- & 0.9620 & 0.0333 \\
\hline Halsey (1983) & 0.7671 & 0.0004 & 2.3423 & ------- & ------ & 0.9551 & 0.0362 \\
\hline
\end{tabular}


Regarding the equations that do not consider temperature and vapor pressure of saturation as a variable, the best values of $\mathrm{R}^{2}$ were obtained with the equation of Jaafar and Michalowski (1990) for both tested temperatures $\left(40\right.$ and $50{ }^{\circ} \mathrm{C}$ ). This result is in agreement with the work of Nascimento et al. (2008), in which the authors compared 41 mathematical models of sorption isotherms for 53 food products and found that the best agreement was obtained with the model of Jaafar and Michalowski (1990). A comparison between the experimental data and the data predicted by the Jaafar and Michalowski model for temperatures of 40 and $50{ }^{\circ} \mathrm{C}$ are shown in Figure 5. Table 7 shows the parameters obtained by comparing the mathematical models, in which temperature was a variable, with the sugarcane bagasse desorption isotherms.

With respect to the equations that consider temperature and vapor pressure of saturation as a variable, the best agreement with the experimental data for the two temperatures was obtained with the modified Henderson II model (PAKOWSKI, 1995), due to the higher $\mathrm{R}^{2}$ value $(0.89090)$ and lower SE value (0.07980). A comparison between the experimental data and the data predicted using the modified Henderson II model is shown in Figure 6.

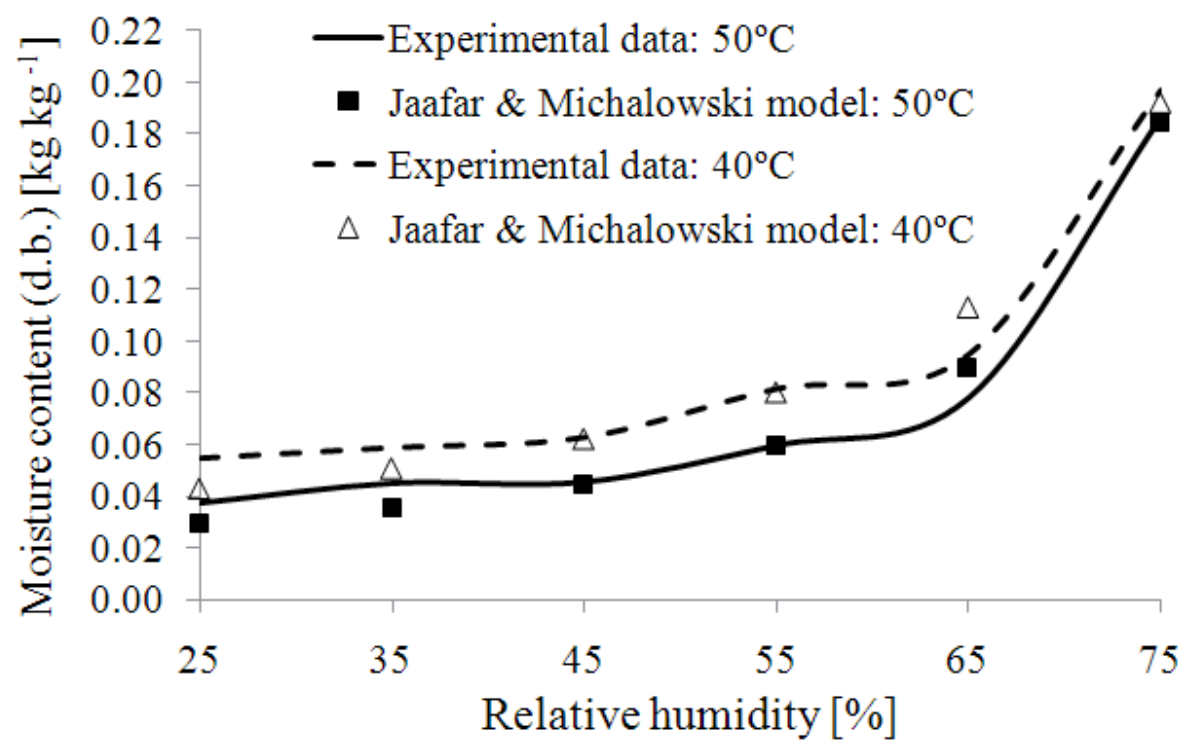

Figure 5. Desorption isotherm of sugar cane bagasse compared to the Jaafar and Michalowski model at 40 and $50{ }^{\circ} \mathrm{C}$.

Table 7. Parameters of the desorption isotherm models and agreements for sugarcane considering temperature and vapor pressure of saturation as a variable.

\begin{tabular}{cccccc}
\hline \multirow{2}{*}{ Models } & \multicolumn{5}{c}{ Constants } \\
\cline { 2 - 6 } & $\mathrm{S}_{1}$ & $\mathrm{~S}_{2}$ & $\mathrm{~S}_{3}$ & $\mathrm{R}^{2}$ & $\mathrm{SE}$ \\
\hline $\begin{array}{c}\text { Modification Henderson I } \\
\text { (Pakowski, 1995) }\end{array}$ & 0.0016 & -7.287 & 0.9446 & 0.7552 & 0.1195 \\
\hline $\begin{array}{c}\text { Modification Henderson II } \\
\text { (Pakowski, 1995) }\end{array}$ & 0.7600 & 2.9944 & 1.7771 & 0.8909 & 0.0798 \\
\hline $\begin{array}{c}\text { Modification Henderson III } \\
\text { (Madamba et al., 1995) }\end{array}$ & 0.1921 & -3.502 & 0.92697 & 0.8000 & 0.1080 \\
\hline
\end{tabular}

\section{REVENG}

128-142p. ENGENHARIA NA AGRICULTURA, VIÇOSA - MG, V.23 N.2, MARÇO / ABRIL 2015 


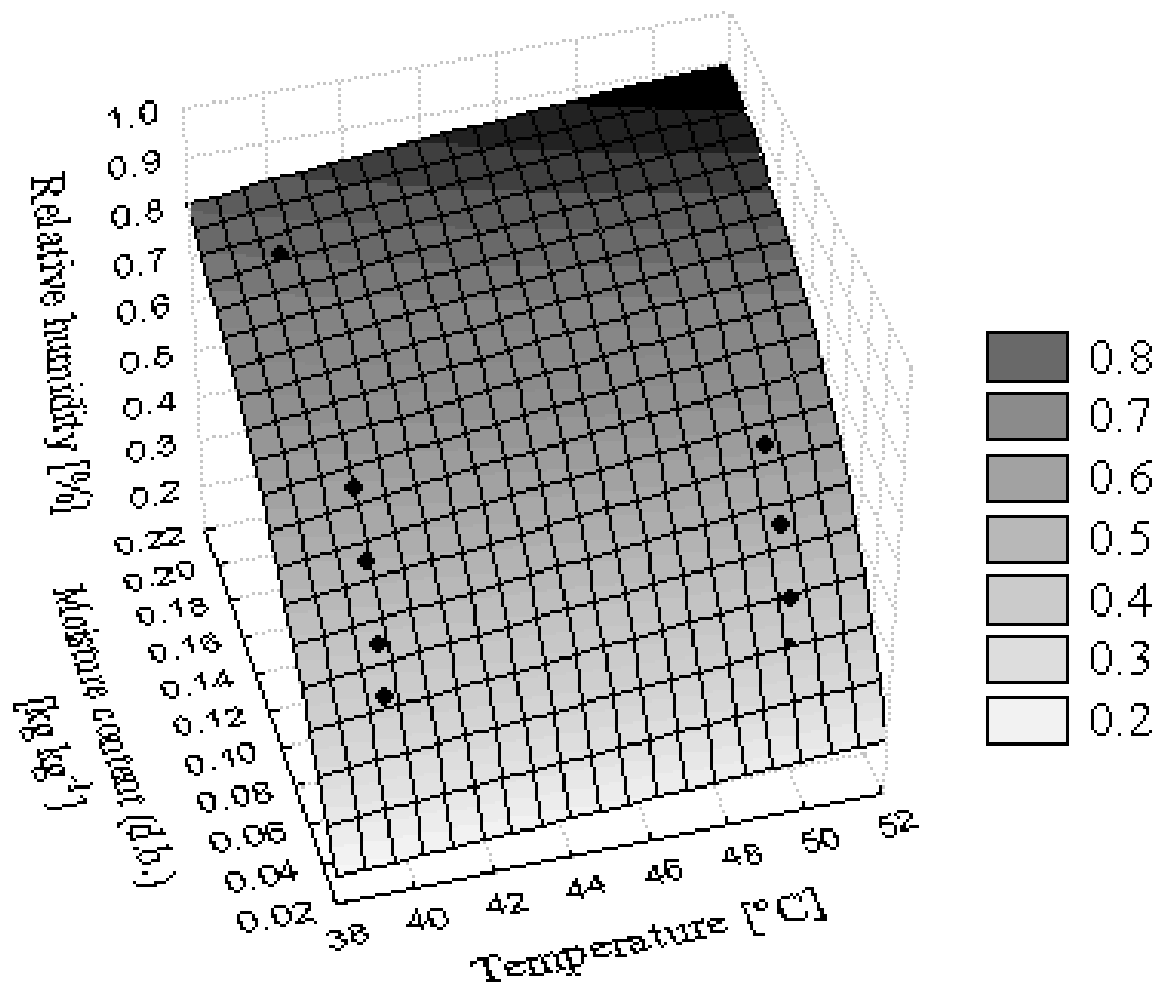

Figure 6. Comparison of experimental data for the sugarcane bagasse isotherm with the isotherm predicted by the Modified Henderson II model.

\section{CONCLUSIONS}

- Of the 13 mathematical models tested, the best prediction of the kinetics of fixed bed drying of sugarcane bagasse at 40,50 and $60{ }^{\circ} \mathrm{C}$ was obtained with the Modified Page 2 model;

- Among the mathematical models in which temperature is not considered a variable, the model of Jaafar and Michalowski (1990) provided the best agreement with experimental data at 40 and $50{ }^{\circ} \mathrm{C}$ for the sugarcane bagasse desorption isotherms. Of those in which temperature is considered a variable, the best agreement with experimental data was obtained with the modified Henderson II equation.

\section{ACKNOWLEDGEMENTS}

The authors acknowledge the financial support provided by FAPEMIG (Process 2021305 and CAG APQ-3415-3.12/07) and FINEP (Project 01.06.0047.00) and thank the Junqueira sugar company (COSAN) as well as the Ester sugar company for the bagasse sugarcane samples.

\section{REFERENCES}

ANDERSON, R. B.; HALL, W.K. Sorption Studies on American Coals. Journal of the American Chemical Society, v.70, p.1727-1734, 1948.

ALARCÓN, G.A.R.; JÚSTIZ, M.A.B. Industrial device for drying and classifying sugar cane bagasse. International Sugar Journal, v.95, p.319-322, 1993.

AOAC. Official Methods of Analysis of the Association of Official Analytical Chemists. Official Method 934.06. AOAC International, Arlington, VA, USA, 1990.

AYENSU, A. Dehydration of food crops using a solar dryer with convective heat flow. Solar Energy, v.59, p.121-126, 1997. 
BELTING, K.W.; SEMRAU, P.G. Bagasse drying by flash-drier in Brazil and some theoretical considerations. Zuckerindustrie, v.134, p.413417, 2009.

CAI, J.; CHEN, S. Determination of Drying Kinetics for Biomass by Thermogravimetric Analysis under Nonisothermal Condition. Drying Technology, v.26, p.1464-1468, 2008.

CAURIE, M. A new model equation for predicting safe moisture levels for optimum stability of dehydrated foods. Journal of Food Technology, v.5, p.301-307, 1970.

CORRÊA，J.L.G.; GRAMINHO, D.R.; SILVA, M.A.; NEBRA, S.A. Cyclone as a sugar cane bagasse dryer. Chinese Journal of Chemical Engineering, v.12, p.826-830, 2004.

DE OLIVEIRA, L.F.; CORRÊA, J.L.G.; TOSATO, P.G.; Borges, S.V.; Alves, J.G.L.F.; Fonseca, B.E. Sugarcane bagasse drying in a cyclone: Influence of device geometry and operational parameters. Drying Technology, v.29, p.946-952, 2011.

DE TERMMERMAN, J.; VERBOVEN, P.; DELCOUR, J.A.; NICOLAÏ, B.; RAMON, H. Drying model for cylindrical pasta shapes using desorption isotherms. Journal of Food Engineering, v.86, p.414-421, 2008.

DIAS, M.O.S.; ENSINAS, A.V.; NEBRA, S.A.; MACIEL FILHO, R.; ROSSELL, C.E.V.; MACIEL, M. R.W. Production of bioethanol and other bio-based materials from sugarcane bagasse: Integration to conventional bioethanol production process. Chemical Engineering Research \& Design, v.87, p.1206-1216, 2009.

DOYMAZ, I.; GOREL, O.; AKGUN, N.A. Drying characteristics of the solid by-product of olive oil extraction. Biosystems Engineering, v.88, p.213$219,2004$.

DOYMAZ, I. Convective air drying characteristics of thin layer carrots. Journal of Food Engineering, v.61, p.359-364, 2004.
DOYMAZ, I. Thin-layer drying behavior of mint leaves. Journal of Food Engineering, v.74, p.370$375,2006$.

DOYMAZ, I. Convective drying kinetics of strawberry. Chemical Engineering and Processing, v.47, p.914-919, 2008.

FURMANIAK, S.; TERZYK, A.P.; GOLEMBIEWSKI, R.; GAUDEN, P.A.; CZEPIRSKI, L. Searching the most optimal model of water sorption on foodstuffs in the whole range of relative humidity. Food Research International, v.42, p.1203-1214, 2009.

GUNHAN, T.; DEMIR, V.; HANCIOGLU, E.; HEPBASLI, A. Mathematical modelling of drying or bay leaves. Energy Conversion and Management, v.46, p.1667-1679, 2005.

HAILWOOD, A.J.; HORROBIN, S.S. Adsorption of water by polymers: analysis in terms of a simple model. Transactions of the Faraday Society, v.42B, p.8492, 1946.

HALSEY, G.J. Physical adsorption on non-uniform surfaces. Journal of Chemical Physical, v.16, p.931-937, 1983.

HARKINS, W.; JURA, G. Surface of solids. X. Extension of the attractive energy of a solid into an adjacent liquid or film, the decrease of energy with distance, and the thickness of films. Journal American Chemical Society, v.66, p.919-927, 1944.

HENDERSON, S.M.; PABIS, S. Grain drying theory I: temperature effect on drying coefficient. Journal of Agricultural Engineering Research, v.6, p.169-174, 1961.

HOSSAIN, M.A.; WOODS, J.L.; BALA, B.K. Single-layer drying characteristics and colour kinetics of red chilli. International Journal of Food Science and Technology, v.42, p.13671375, 2007.

HUTTIG, G.F.; THEIMER, O. Zur theorie der 
adsorption I. Colloid \& Polymer Science, v.119, p.69-73, 1950.

JAAFAR, F.; MICHALOWSKI, S. Modified BET equation for sorption/dessorption isotherms. Drying Technology, v.8, p.811-827, 1990.

JAIN, C.K.; KUMAR, A.; IZAZY, M.H. Color removal from paper mill effluent through adsorption technology. Environmental Monitoring and Assessment, v.149, p.343-348, 2009.

LORA, E.S.; ANDRADE, R.V. Biomass as energy source in Brazil. Renewable \& Sustainable Energy Reviews, v.13, p.777-788, 2009.

KROKIDA, M.K.; MAROULIS, Z.B.; KREMALIS, C. Process design of rotary dryers for olive cake. Drying Technology, v.20, p.771-787, 2002.

KÜHN, I. Adsorption isotherms. Journal of College Science, Japan, Tokyo, v.19, p.685-698, 1964.

KUROZAWA, L.E.; EL-AOUAR, A.A.; MURR, F.E.X. Obtenção de isotermas de dessorção de cogumelo in natura e desidratado osmoticamente. Ciência e Tecnologia de Alimentos, v.25, p.828834, 2005.

MADAMBA, P.S.; DRISCOLL, R.H.; BUCKLE, K.A. Drying Techonology, v.13, p.295-317, 1995.

MADHIYANON, T.; PHILA A.; SOPONRONNARIT, S. Models of fluidized bed drying for thin-layer chopped coconut. Applied Thermal Engineering, v.29, p.2849-2854, 2009.

MAZUTTI, M.A.; ZABOT, G.; BONI, G.; SKOVRONSKI, A.; OLIVEIRA, D.; DI LUCCIO, M.; OLIVEIRA, J.V.; RODRIGUES, M.I.; TREICHEL, H.; MAUGERI, F. Mathematical modeling of thin-layer drying of fermented and non-fermented sugarcane bagasse. Biomass and bioenergy, v.34, p.780-786, 2010.

MIDILLI, A.; KUCUK, H.; YAPAR, Z. A new model for single-layer drying. Drying Technology, v.20, p.1503-1513, 2002.

MODA, E.M.; HORII, J.; SPOTO, M.H.F. Edible mushroom Pleurotus sajor-caju production on washed and supplemented sugarcane bagasse. Scientia Agricola, v.62, p.127-132, 2005.

MORGADO, I.F.; CARNEIRO, J.G.A.; LELES, P.S.S.; BARROSO, D.G. Resíduos agroindustriais prensados como substrato para a produção de mudas de cana-de-açúcar. Scientia Agricola, v.57, p.709-712, 2000.

NASCIMENTO, F.R.; TOSATO, P.G.; CORRÊA, J.L.G. Sorption isotherms for food stocks: study of models agreement. Proceeding 16th International Drying Symposium, Hyderabad, India, 2008.

NEBRA, S.A.; MACEDO, I.C. Bagasse particle shape and size and their free-setting velocity. International Sugar Journal, v.90, p.168-170, 1988.

NGUYEN, T.L.T.; HERMANSEN, J.E.; SAGISAKA, M. Fossil energy savings potential of sugar cane bio-energy systems. Applied Energy, v.86, p.S132-S139, 2009.

OVERHULTS, D.G.; WHITE, G.M.; HAMILTON, H.E.; ROSS, I.J. Drying soybeans with heated air. Transactions of the ASAE, v.16, p.112-113, 1973.

PAGE, G.E. Factors influencing the maximum of air drying shelled corn in thin layer. 1995. 103f. Thesis (Physical doctor), Purdue University, Indiana, 1949.

PAKOWSKI, Z. DryPak v.1.3. Society of Polish Consultants, Lodz Office, 1995.

PALACIOS-BERECHE, R. MOSQUEIRASALAZAR, K.J.; MODESTO, M.; ENSINAS, A.V. NEBRA, S.A.; SERRA, L.M.; LOZANO, M.A. Exergetic analysis of the integrated firstand second-generation ethanol production from sugarcane. Energy, v.62, p.46-61, 2013.

PELEG, M. Assessment of a semi-empirical four 
parameter general model for sigmoid moisture sorption isotherms. Journal of Food Process Engineering, v.16, p.21-37, 1993.

Pereira, R.A.N.; FERREIRA, W.M.; GARCIA, S.K.; PEREIRA, M.N.; BERTECHINI, A.G. Digestibilidade do bagaço de cana-de-açúcar tratado com hidróxido de sódio em dietas para coelhos em crescimento. Ciência e Agrotecnologia, v.32, p.573-577, 2008.

PURANIK, V.S.; YARNAL, G.S. Improved method of bagasse drying for energy saving in sugar industries. International Sugar Journal, v.111, p.572-581, 2009.

RASUL, M.G.; RUDOLPH, V.; CARSKY, M. Physical properties of bagasse. Fuel, v.78, p.905910, 1999.

RÍPOLI, T.C.C.; MOLINA JR. W.F.; RÍPOLI, M.L.C. Energy potential of sugar cane biomass in Brazil. Scientia Agricola, v.57, p.677-681, 2000.

ROCHA, M.H.H.; SUSIN, I.; PIRES, A.V.; FERNANDES, J.D.; MENDES, C.Q. Performance of Santa Ines lambs fed diets of variable crude protein levels. Scientia Agricola, v.61, p.141-145, 2004.

SHARAFELDEEN, Y.I.; BLAISDELL， J.L.; HAMDY, M.Y. A model for ear corn drying. Transactions of the ASAE, v.23, p.1261, 1980.

SHI, J.L.; PAN, Z.L.; MCHUGH, T.H.; WOOD, D.; HIRSCHBERG E.; OLSON, D. Drying and quality characteristics of fresh and sugar-infused blueberries dried with infrared radiation heating. Lwt-Food Science and Technology, v.41, p.19621972, 2008.

SIQUEIRA, F.G.; DIAS, E.S.; DA SILVA, R.; MARTOS, E.T.; RINKER, D.L. Cultivation of Agaricus blazei ss. Heinemann using different soils as source of casing materials. Scientia Agricola, v.66, p.827-830, 2009.

SOBUKOLA, O.P.; DAIRO, O.U.; ODUNEWU, A.V. Convective hot air drying of blanched yam slices. International Journal of Food Science and Technology, v.43, p.1233-1238, 2008.

SOSA-ARNAO, J.H.; NEBRA, S.A. Bagasse Dryer Role in the Energy Recovery of Water Tube Boilers. Drying Technology, v.27, p.587-594, 2009.

SOSA-ARNAO, J.H.; CORRÊA, J.L.G.; SILVA, M.A.; NEBRA, S.A. Sugar cane bagasse drying: a review. International Sugar Journal, v.108, p.381-392, 2006.

TIRADO, M.L.B.; AREA, C.M.; VELEZ, H.E. Optimizing alkaline sizing in sugar cane bagasse paper recycling. Cellulose Chemistry and Technology, v.43, p.179-187, 2009.

TRAYNER, P. Bagasse transport and storage for the Pioneer cogeneration project. International Sugar Journal, v.110, p.475-481, 2008.

VERMA, B.; SHUKLA, N.P. Removal of Nickel(II) from electroplating industry effluent by agrowaste carbons. Indian Journal Environmental Health, v.42, p.145-150, 2000.

VIJAYARAJ, B.; SARAVANAN, R.; RENGANARAYANAN. S. Studies on thin layer drying of bagasse. International Journal of Energy Research, v.31, p.422-437, 2007.

WANG, C.Y.; SINGH, R.P. A single layer drying equation for rough rice. The Society for Engineering in Agricultural, Food, and Biological Systems, Paper No 78-3001, 1978.

YALDIZ, O.; ERTEKIN, C. Thin layer solar drying of some different vegetables. Drying Technology, v.19, p.583-597, 2001. 